\title{
Osobine ličnosti učenika, strategije samoregulacije učenja i suočavanja sa školskim neuspjehom, dob i rod kao prediktori objektivnoga i subjektivnoga školskog uspjeha
}

\author{
Anela Nikčević-Milković \\ Odjel za nastavničke studije u Gospiću Sveučilišta u Zadru, Gospić, Hrvatska \\ Sanja Tatalović Vorkapić \\ Sveučilište u Rijeci, Učiteljski fakultet u Rijeci, Rijeka, Hrvatska
}

\begin{abstract}
Sažetak
Cijeli niz istraživanja potvrđuje povezanost između osobina ličnosti, samoregulacije učenja i školskoga postignuća, iako te povezanosti nisu jednostavne. Osobine ličnosti važni su prediktori objašnjenja samoregulacije učenja, a jedno i drugo važni su prediktori objašnjenja objektivnoga i subjektivnoga školskog uspjeha, odnosno zadovoljstva školom. Osnovni je cilj ovoga istraživanja bio ispitati u kojoj mjeri demografske karakteristike učenika (dob i rod), osobine ličnosti, (meta)kognitivne strategije učenja, strategije suočavanja sa školskim neuspjehom i strategije traženja socijalne podrške (kao prediktori) objašnjavaju objektivni i subjektivni školski uspjeh (kao kriterije). U istraživanju je sudjelovalo 457 učenika 6. i 8. razreda osnovne škole i 2. razreda srednje škole iz četiriju osnovnih i triju srednjih škola u Republici Hrvatskoj. Rezultati pokazuju da se s povećanjem dobi smanjuje objektivni školski uspjeh. Učenice imaju veći objektivni školski uspjeh, kao i savjesniji učenici te oni učenici koji manje koriste maladaptivne strategije površinskoga kognitivnog procesiranja informacija (što je i najznačajniji negativni prediktor objektivnoga školskog uspjeha). Navedeni set prediktora uspješno je objasnio $29 \%$ objektivnoga školskog uspjeha kao kriterija. S povećanjem dobi učenika smanjuje se i subjektivni školski uspjeh. Učenici koji su viši na osobini Ugodnosti, koji manje koriste maladaptivne strategije zaštite emocija udaljavanjem prilikom suočavanja sa školskim neuspjehom, a više rabe adaptivne strategije traženja emocionalne i instrumentalne podrške od prijatelja, imaju veći subjektivni školski uspjeh. Navedeni set prediktora uspješno je objasnio $18 \%$ subjektivnoga školskog uspjeha kao kriterija.
\end{abstract}

Ključne riječi: osobine ličnosti, strategije samoregulacije učenja, dob i rod učenika, objektivno i subjektivno školsko postignuće

\section{Uvod}

Osnovni su rezultat i cilj odgojno-obrazovnoga procesa njegovi ishodi te školsko postignuće. Samim se time pitanje ostvarivanja zadovoljavajuće razine

Anela Nikčević-Milković, Odjel za nastavničke studije u Gospiću Sveučilišta u Zadru, dr. A. Starčevića 12, 53000 Gospić, Hrvatska. E-pošta: amilkovic@unizd.hr 
školskoga postignuća nameće kao ključno u okviru primijenjene psihologije (VizekVidović i sur., 2014). Pritom je suvremena psihologija obrazovanja dominantno usmjerena na proučavanje kognitivnih, ali i čitav niz tzv. ne-kognitivnih determinanti procesa učenja i poučavanja (Tatalović Vorkapić, 2017), u podlozi čega leže vrlo jasni, empirijski utemeljeni argumenti (Morosanova i sur., 2018; Tatalović Vorkapić, 2012, 2015). Oni se baziraju na činjenici da treba zauzeti holistički pristup te analizirati sve faktore koji mogu imati značajan efekt na razinu školskoga postignuća. Stoga je razumljivo da odgojno-obrazovni proces podrazumijeva interakciju značajnoga broja čimbenika koji povoljno ili nepovoljno utječu na ishode učenja.

Početna kategorizacija spomenutih čimbenika odnosi se na one faktore koji su vezani uz učenika, učitelja, procese, materijale i metode učenja i poučavanja te različite međusobne interakcije (Vizek-Vidović i sur., 2014). U kontekstu odgojnoobrazovnoga procesa svaki od navedenih čimbenika može biti sagledavan iz kognitivnoga i ne-kognitivnog aspekta, a u fokusu su ovoga istraživanja osobine ličnosti učenika, njihove strategije samoregulacije učenja, dob i rod. Prema Caprari i suradnicima (2011) efekt ličnosti značajno je dugotrajniji i stabilniji od motivacije i samoregulacije. Najveći je broj istraživanja dosad empirijski dokazao dominantnost efekta savjesnosti, kao jedne od pet dimenzija ličnosti prema Petofaktorskome modelu ličnosti (Costa i McCrae, 1985, 1992), u odgojno-obrazovnome procesu i kontekstu. Prema Pervinu i suradnicima (2008) pet faktora ličnosti - Savjesnost (S), Neuroticizam (N), Ekstraverzija (E), Otvorenost (O) i Ugodnost (U) - osnovne su dispozicijske sklonosti, univerzalne su te ih svaki pojedinac ima u određenoj mjeri. U odnosu s drugim ne-kognitivnim faktorima, jednako važnima u proučavanju školskoga postignuća, značajnim medijatorom osobina ličnosti u odnosu sa školskim postignućem pokazala se samoregulacija učenja (Bidjerano i Dai, 2007).

Strategije učenja predstavljaju operacije koje učenik koristi da si olakša stjecanje, pohranu ili dosjećanje informacija (Oxford, 1990). Starija djeca proizvode složenije strategije, bolje ih povezuju sa zadatcima, vještiji su u njihovu korištenju, što dovodi do boljega učenja i pamćenja. Prema Rijavec i suradnicima (1999) učenici boljega školskog uspjeha više koriste duboko procesiranje informacija i adaptivne strategije učenja, dok lošiji učenici uglavnom koriste memoriranje i manje adaptivnu strategiju ponavljanja. Prema Lončariću (2008) postoje rodne razlike u samoregulaciji učenja: djevojčice uglavnom imaju proaktivan obrazac samoregulacije učenja, veći osjećaj školske samoefikasnosti, više koriste proaktivne strategije učenja te motivacijske i organizacijske strategije, dok su dječaci usmjereniji na obrambeni obrazac samoregulacije učenja, imaju ciljne orijentacije koje se odnose na pokazivanje znanja i vještina kroz natjecanje, pokazivanje vlastitih sposobnosti i izbjegavanje mogućnosti neuspjeha te neškolske ciljeve, poput želje za socijalnom afirmacijom i izbjegavanjem truda. Pri učenju dječaci su usmjereni na minimalne zahtjeve nastavnika i češće koriste strategije nepovezanoga memoriranja, samohendikepiranja, obrambenoga pesimizma i vanjskoga atribuiranja školskoga 
neuspjeha. Mlađi učenici osnovnoškolske dobi imaju veći potencijal za proaktivnu samoregulaciju učenja $\mathrm{u}$ usporedbi sa starijim učenicima koje uglavnom karakterizira obrambeni obrazac samoregulacije (Lončarić, 2010).

Strategije suočavanja sa školskim neuspjehom predstavljaju strategije suočavanja sa stresom unutar školske domene. Ocjenjivanje je znanja kod $59 \%$ učenika čest ili vrlo čest stresor, a pritisak roditelja zbog ocjena često ili vrlo često doživljava $45 \%$ učenika (De Anda i sur., 2000). Dobivanje loše ocjene ili ocjene lošije od očekivane specifičan je izvor školskoga stresa jer dijete ili adolescent to percipira kao napad na njegovu dobrobit. Načini rješavanja problema mijenjaju se u funkciji dobi. Stariji adolescenti imaju veći repertoar raspoloživih strategija, ali s dobi raste učestalost primjene kako učinkovitih, tako i neučinkovitih strategija suočavanja (Williams i McGillicuddy-De Lisi, 2000). Mlađi učenici rjeđe od roditelja skrivaju lošu ocjenu te su skloniji traženju njihove pomoći u odnosu na srednjoškolce (Rijavec i Brdar, 1997). Socijalna podrška vršnjaka postaje sve bitnija i kontinuirano raste s dobi (Seiffge-Krenke, 1993). Na suočavanje s neuspjehom bitno utječe djetetov kognitivni i socijalni razvoj koji mu pomaže u otkrivanju i korištenju novih resursa za suočavanje. Korištenje tih strategija razlikuje se i s obzirom na rod. Djevojke doživljavaju veći broj stresnih događaja i intenzitet doživljavaju većim, anksioznije su, imaju niže samopoštovanje, više sumnjaju u svoje sposobnosti te su sklonije samookrivljavanju za neuspjehe (Brdar i sur., 2006). Iako su u mnogim istraživanjima dokazane rodne razlike u načinima suočavanja, među njima postoji određen stupanj neslaganja. Nejednoznačni rezultati u pogledu roda i dobi kao odrednica suočavanja pokazuju da se oni trebaju promatrati istovremeno.

Strategije traženja socijalne podrške pojedinci koriste u nekim stresnim situacijama. Mreže socijalne podrške mogu služiti kao zaštitni čimbenik u procesu suočavanja ili mogu izravno poboljšati dobrobit pojedinca (Greenglass, 1993). Thoits (1986) smatra da suočavanje i socijalna podrška imaju zajedničke funkcije koje mogu biti instrumentalne (konkretna pomoć), emocionalne (ublažavanje negativnih emocija) i perceptivne (drugačije sagledavanje situacije), uključujući i informacijsku podršku. Učenici koji znaju kada, kako i od koga tražiti pomoć trebali bi biti uspješniji od onih koji ne traže pomoć na odgovarajući način (Newman, 1994). Prema Lončariću (2014) istraživanja pokazuju da je traženje pomoći od roditelja pozitivno, a traženje pomoći od vršnjaka/prijatelja negativno povezano sa školskim uspjehom. Također je važna i vrsta pomoći koja se traži: neki učenici traže pomoć kako bi naučili i savladali gradivo, dok drugi traže da im drugi izvrše zadatak (Garcia i Pintrich, 1994).

Mnoga su istraživanja potvrdila da učenici koji rabe adaptivne komponente samoreguliranoga učenja imaju bolji školski uspjeh (Nikčević-Milković i Perković, 2000; Rijavec i sur., 1999; Tomljenović i Nikčević-Milković, 2005). Mlađi učenici imaju bolji školski uspjeh, ulažu više truda, odnosno motivacija za školu opada u funkciji dobi (Eccles i sur., 1989; Nikčević-Milković i sur., 2014). Razlog je dijelom 
u fiziološkim promjenama puberteta koje nastupaju, ali i u poteškoćama u prilagodbi vezanima za prijelaz iz osnovne u srednju školu.

Jako je malo istraživanja zadovoljstva školom, kao i istraživanja povezanosti objektivnoga školskog uspjeha, zadovoljstva školom i samoregulacije učenja. Istraživanje Verkuytena i Thijsa (2002) pokazuje da je zadovoljstvo školom povezano $\mathrm{s}$ objektivnim školskim postignućima te $\mathrm{s}$ osjećajem samoefikasnosti učenika. Učenice su zadovoljnije školom u odnosu na učenike, što navedeni autori objašnjavaju time da su djevojčice/djevojke više okrenute odnosima s drugim ljudima, a škola im upravo to i nudi.

Poropat (2009) navodi da, iako sugestivni, argumenti o povezanosti crta ličnosti i školskih postignuća nisu uvjerljivi jer korelacije u istraživanjima nisu dovoljno visoke. Ta činjenica naglašava važnost izravnoga testiranja odnosa crta ličnosti i školskoga postignuća. De Raad i Schouwenburg (1996) navode da ugodnost ima pozitivan utjecaj na školsko postignuće jer olakšava procese učenja. Kasnija su istraživanja otkrila da je ugodnost povezana s poštivanjem uputa nastavnika, trudom i ustrajnošću (Vermetten i sur., 2001). Savjesnost je povezana s motivacijom za postignućem, ustrajnošću i postavljanjem ciljeva (Barrick i sur., 1993), što je pak povezano sa školskim uspjehom (Steel, 2007), ustrajnošću u pisanju domaćih zadaća (Trautwein i sur., 2006) te upravljanjem vremenom i reguliranjem truda (Bidjerano i Dai, 2007). De Raad i Schouwenburg (1996) navode da su pojedinci koji su niski na osobini emocionalne stabilnosti zabrinutiji i imaju tendenciju da se usredotoče na svoje emocionalno stanje i razgovor sa samim sobom, što im ometa pozornost usmjerenu na školske zadatke i time im se smanjuje školska izvedba. Emocionalna stabilnost povezana je sa samoefikasnošću (Judge i sur., 2002), što je pak pozitivno povezano sa školskim postignućem (Robbins i sur., 2004). De Raad i Schouwenburg (1996) tvrdili su da su učenici koji su visoko na razini ekstraverzije uspješniji u školskim postignućima zbog više razine energije, kao i pozitivnijega stava prema učenju, međutim, Eysenck i Van Berkum (1992) navode da će se ti učenici prije socijalizirati i započinjati druge aktivnosti osim učenja, što će dovesti do nižih razina postignuća. Prema De Raadu i Schouwenburgu (1996) osobina otvorenost odražava „idealnoga učenika“ zbog povezanosti s predviđanjem, inteligencijom i spretnošću. Povezana je s pozitivnim pristupom učenju, motivacijom za postignućem i kritičkim mišljenjem.

Cilj je ovoga istraživanja bio ispitati u kojoj mjeri osobine ličnosti, (meta)kognitivne strategije učenja, strategije suočavanja sa školskim neuspjehom i strategije traženja socijalne podrške te dob i rod učenika objašnjavaju objektivni i subjektivni školski uspjeh. Povezanosti tih varijabli u dosadašnjim istraživanjima nisu bile jednoznačne. Budući da su dosadašnja istraživanja pokazala kako osobine ličnosti i razvijene adaptivne (meta)kognitivne strategije učenja i suočavanja sa školskim neuspjehom pridonose boljoj školskoj i socijalnoj prilagodbi učenika, očekuje se da će savjesniji, otvoreniji, ekstravertiraniji, emocionalno stabilniji i ugodniji učenici imati veći objektivni školski uspjeh (engl. GPA), kao i veće 
zadovoljstvo školom. Također, istraživanja sugeriraju da se s porastom dobi učenika može predvidjeti smanjenje školskoga uspjeha (objektivnoga i subjektivnoga), porast uporabe učinkovitih (adaptivnih), ali i neučinkovitih (maladaptivnih) strategija samoregulacije učenja, te da će veće korištenje adaptivnih i manje korištenje maladaptivnih strategija učenja i suočavanja sa školskim neuspjehom i ženski rod učenika predvidjeti bolji školski uspjeh.

\section{Metoda}

\section{Sudionici}

U istraživanju je sudjelovalo 457 učenika (od toga 243 ili 53 \% ženskog roda) u dobi od 12 do 16 godina iz četiriju osnovnih i triju srednjih škola (dviju općih gimnazija i jedne strukovne škole). Prigodnim uzorkom škola bio je obuhvaćen 151 učenik 6. razreda ( $33 \%)(M$ dob $=12.02$ godina, $S D=0.43$, ženski $=79)$ i 87 učenika 8. razreda $(19 \%)(M$ dob $=14.06$ godina, $S D=0.36$, ženski $=51)$ osnovne škole te 217 učenika 2. razreda srednje škole $(48 \%)(M \mathrm{dob}=16.02$ godina, $S D=0.45$, ženski $=113$ ).

\section{Instrumenti}

Za mjerenje crta petofaktorskoga modela ličnosti korišten je Big Five Inventory (BFI; Benet-Martinez i John, 1998) čija je validacija u Republici Hrvatskoj potvrdila originalnu strukturu (Kardum i sur., 2006). Sastoji se od 44 čestice. Odgovori su na skali Likertova tipa od 5 stupnjeva (od 1 - Uopće se ne slažem do 5 -U potpunosti se slažem). Čestice unutar pojedinih dimenzija pokrivaju različite facete, odnosno uže komponente pojedinih faktora. Pouzdanosti unutarnje konzistencije (Cronbachova alfa) u istraživanju Krapić i sur. (2008) kreću se od .60 za Ugodnost, .72 za Neuroticizam, .76 za Otvorenost, .77 za Savjesnost do .79 za Ekstraverziju, dok se u ovome istraživanju kreću od .62 za Ekstraverziju, .70 za Ugodnost, .72 za Neuroticizam i Otvorenost, te 73 za Savjesnost.

Skala strategija učenja (SSU; Lončarić, 2014) predstavlja komponentu samoreguliranoga učenja koja se odnosi na (meta)kognitivne strategije. Služi za mjerenje strategija učenja kroz osam subskala grupiranih u tri komponente: 1) Ciklus (meta)kognitivne kontrole učenja (Ponavljanje i uvježbavanje; Kontrola tijeka i ishoda učenja); 2) Duboko kognitivno procesiranje (Elaboracija; Organizacija; Primjena; Kritičko mišljenje); 3) Površinsko kognitivno procesiranje (Usmjerenost na minimalne zahtjeve; Memoriranje). Odgovori su na skali Likertova tipa od 5 stupnjeva (od 1 - Uopće se ne slažem do 5 - U potpunosti se slažem). Pouzdanost unutarnje konzistencije (Cronbachova alfa) u ovome istraživanju za cijelu je skalu .90 , a za pojedine subskale kreće se od .79 do .90 . 
Skala suočavanja sa školskim neuspjehom (SUN; Lončarić, 2014) predstavlja samoprocjenu nastojanja učenika da se suoče sa školskim neuspjehom i odnosi se na strategije samoregulacije u procesu učenja koje se aktiviraju nakon doživljenoga neuspjeha. Sastoji se od osam subskala grupiranih u tri komponente: 1) Suočavanje usmjereno na problem (Aktivno rješavanje problema; Razmišljanje o problemu);2) Zaštita emocija udaljavanjem (Izbjegavanje; Maštanje; Skretanje pažnje); 3) Zaštita ega udaljavanjem (Odustajanje i reinterpretacija; Ignoriranje problema; Ismijavanje problema). Odgovori su na skali Likertova tipa od 5 stupnjeva (od 1 -Uopće se ne slažem do 5 - U potpunosti se slažem). Prema Lončariću pouzdanost skale provjerena je koeficijentima pouzdanosti tipa unutarnje konzistencije, koji se kreću od .75 za skalu Maštanja do .89 za skalu Skretanja pažnje, a u ovome istraživanju kreću se od .70 za skalu Ignoriranja problema do .87 za skalu Maštanja.

Skala traženja socijalne podrške (TSP; Lončarić, 2014) mjera je usmjerenosti učenika na socijalnu podršku u situacijama školskoga neuspjeha. Sastoji se od 18 čestica grupiranih u četiri subskale: 1) Traženje emocionalne $i$ instrumentalne podrške od prijatelja; 2) Traženje emocionalne $i$ instrumentalne podrške od roditelja; 3) Traženje emocionalne podrške od nastavnika; 4) Traženje instrumentalne podrške od nastavnika. Odgovori su na skali Likertova tipa od 5 stupnjeva. Prema navedenome autoru pouzdanost subskala provjerena je koeficijentima pouzdanosti tipa unutarnje konzistencije, koji iznose od .85 za skalu Traženja emocionalne podrške od nastavnika do .89 za skalu Traženja emocionalne i instrumentalne podrške od prijatelja, a u ovome istraživanju kreću se od .84 za skalu Traženja emocionalne podrške od nastavnika do .90 za skalu Traženja emocionalne $\mathrm{i}$ instrumentalne podrške od roditelja.

Zadovoljstvo školom mjereno je jednom tvrdnjom formata odgovora od pet stupnjeva (od 1 - Uopće nisam zadovoljan do 7 - U potpunosti sam zadovoljan).

Anketnim listom sociodemografskih podataka učenika dobiveni su podatci o razredu, rodu, općemu školskom uspjehu te uspjehu iz školskih predmeta Matematika i Hrvatski jezik na kraju prošloga obrazovnog razdoblja.

\section{Postupak}

Uz dopuštenje odgovornih institucija i pisane dozvole roditelja za sudjelovanje njihove djece $u$ istraživanju, a nakon informiranja o cilju $\mathrm{i}$ načinu provedbe istraživanja, učenici su upitnike popunjavali za vrijeme redovne nastave u školi. Ispitivanje je provedeno anonimno i grupno te je trajalo jedan školski sat. Učenicima je rečeno da u bilo kojemu trenutku mogu svojevoljno odustati od ispunjavanja upitnika. Upitnike su popunjavali pod šifrom koja je služila samo za povezivanje upitnika. Prikupljeni podatci obrađeni su primjenom programskoga sustava Statistica 13.2. 


\section{Rezultati}

\section{Deskriptivna analiza}

U Tablici 1. prikazani su osnovni deskriptivni podatci ispitivanih varijabli.

Tablica 1.

Osnovni deskriptivni podatci za osobine ličnosti, (meta)kognitivne strategije učenja, strategije suočavanja sa školskim neuspjehom, strategije traženja socijalne podrške, prosjek ocjena i zadovoljstvo školom $(N=457)$

\begin{tabular}{ccccccccc}
\hline \multicolumn{1}{c}{$M$} & $S D$ & Asim. & Std. & Spljošt. & Std. & Min & Max \\
\hline Osobine ličnosti i strategije učenja & & & & & & \\
\hline Otvorenost & 3.44 & 0.62 & -0.13 & 0.11 & -0.32 & 0.23 & 1.40 & 4.80 \\
Savjesnost & 3.37 & 0.64 & -0.02 & 0.11 & -0.13 & 0.23 & 1.11 & 5.00 \\
Neuroticizam & 2.66 & 0.67 & 0.33 & 0.11 & -0.04 & 0.23 & 1.00 & 4.63 \\
Ekstraverzija & 3.63 & 0.59 & -0.32 & 0.11 & 0.01 & 0.23 & 1.75 & 1.56 \\
Ugodnost & 3.64 & 0.60 & -0.09 & 0.11 & -0.17 & 0.23 & 5.00 & 5.00 \\
MKK & 3.63 & 1.10 & -0.34 & 0.11 & 0.65 & 0.23 & 11 & 55 \\
DKP & 3.41 & 1.15 & -0.23 & 0.11 & 0.04 & 0.23 & 20 & 100 \\
PKP & 2.71 & 1.28 & 0.26 & 0.11 & -0.38 & 0.23 & 8 & 40 \\
\hline Strategije suočavanja sa školskim neuspjehom & & & & & \\
\hline SSŠN 1 & 3.74 & 1.08 & -0.81 & 0.11 & 0.48 & 0.23 & 8 & 40 \\
SSŠN 2 & 2.98 & 1.41 & -0.09 & 0.11 & -0.25 & 0.23 & 14 & 70 \\
SSŠN 3 & 2.89 & 1.37 & 0.18 & 0.11 & -0.16 & 0.23 & 16 & 80 \\
\hline Strategije traženja socijalne podrške & & & & & & \\
\hline TSP 1 & 3.00 & 1.31 & -0.03 & 0.11 & -0.54 & 0.23 & 6 & 30 \\
TSP 2 & 2.91 & 1.43 & -0.02 & 0.11 & -1.08 & 0.23 & 6 & 30 \\
TSP 3 & 2.22 & 1.44 & 0.83 & 0.11 & -0.29 & 0.23 & 3 & 15 \\
TSP 4 & 3.01 & 1.21 & -0.18 & 0.11 & -0.89 & 0.23 & 3 & 15 \\
\hline Prosjek ocjena & 3.54 & 0.83 & 0.18 & 0.11 & -1.03 & 0.23 & 2 & 5 \\
\hline Zadovoljstvo & 3.10 & 1.12 & -0.25 & 0.11 & 0.86 & 0.23 & 1 & 5 \\
\hline
\end{tabular}

Napomena: MKK - Ciklus (meta)kognitivne kontrole učenja; DKP - Duboko kognitivno procesiranje; PKP - Površinsko kognitivno procesiranje; SSŠN 1 - Suočavanje usmjereno na problem; SSŠN 2 Zaštita emocija udaljavanjem; SSŠN 3 - Zaštita ega udaljavanjem; TSP 1 - Traženje emocionalne i instrumentalne podrške od prijatelja; TSP 2 - Traženje emocionalne i instrumentalne podrške od roditelja; TSP 3 - Traženje emocionalne podrške od nastavnika; TSP 4 - Traženje instrumentalne podrške od nastavnika; $M$ - Aritmetička stredina; $S D$ - Standardna devijacija; Asim. - Asimetrija; Std. pog. asim. - Standardna pogreška asimetrije; Spljošt. - Spljoštenost; Std. pog. spljošt. - Standardna pogreška spljoštenosti; Min - Minimalan rezultat; Max - Maksimalan rezultat.

Sudionici istraživanja najveće rezultate pokazuju na dimenzijama Ugodnosti i Ekstraverzije, u korištenju strategija Ciklusa (meta)kognitivne kontrole učenja, Suočavanja usmjerenoga na problem te Traženja instrumentalne podrške od nastavnika. S obzirom da je normalna distribucija rezultata osnovni uvjet za primjenu parametrijskih analiza, pomoću Kolmogorov-Smirnovljeva $(K-S)$ testa normaliteta distribucije provjereno je koliko rapodjele mjerenih varijabli odstupaju od normalne 
distribucije. Dobiveni rezultati upućuju na određena odstupanja dobivenih distribucija rezultata procjena na pojedinim skalama primijenjenim u ovome istraživanju od normalne krivulje (prema višim vrijednostima). Kline (2005) navodi kako se ekstremno odstupajućim distribucijama mogu smatrati one kod kojih je vrijednost indeksa asimetričnosti veća od 3 , a vrijednost indeksa spljoštenosti veća od 10. Vrijednosti spomenutih indeksa utvrđene u ovome istraživanju (za rezultate pojedinih skala) u okvirima su prihvatljivih za provedbu parametrijskih analiza.

\section{Korelacijske analize}

Iz Tablice 2. vidi se da je između osobina ličnosti, dobi, roda te objektivnoga i subjektivnoga školskog uspjeha niska statistički značajna povezanost. Najviše pozitivne povezanosti dobivene su između Otvorenosti i Savjesnosti s prosjekom ocjena, Ugodnosti i Savjesnosti sa zadovoljstvom školom te Otvorenosti sa ženskim rodom. Najviše negativne povezanosti dobivene su između Otvorenosti i dobi te Neuroticizma i zadovoljstva školom.

Tablica 2.

Povezanosti između dobi, roda te objektivnoga i subjektivnoga školskog uspjeha s osobinama ličnosti učenika

\begin{tabular}{lccccc}
\hline Varijable & Otvorenost & Savjesnost & Neuroticizam & Ekstraverzija & Ugodnost \\
\hline Dob (razred) & $-.23^{*}$ & $-.14^{*}$ & .04 & $-.10^{*}$ & $-.14^{*}$ \\
Rod & $.25^{*}$ & .01 & $.15^{*}$ & $.11^{*}$ & .04 \\
Prosjek ocjena & $.23^{*}$ & $.21^{*}$ & -.01 & $.10^{*}$ & $.13^{*}$ \\
Zadovoljstvo & $.10^{*}$ & $.23^{*}$ & $-.21^{*}$ & .07 & $.31^{*}$ \\
školom & & & & & \\
\hline
\end{tabular}

${ }^{*} p<.05$.

Tablica 3.

Povezanosti između dobi, roda te objektivnoga i subjektivnoga školskog uspjeha sa strategijama samoregulacije učenja ((meta)kognitivnim strategijama učenja, strategijama suočavanja sa školskim neuspjehom i strategijama traženja socijalne podrške)

\begin{tabular}{lcccccccccc}
\hline Varijable & MKK & DKP & PKP & SSŠN 1 & SSŠN 2 & SSŠN 3 & TSP 1 & TSP 2 & TSP 3 & TSP 4 \\
\hline Dob (razred) & $-.26^{*}$ & $-.18^{*}$ & .05 & $-.16^{*}$ & -.09 & $.16^{*}$ & $-.12^{*}$ & $-.33^{*}$ & $-.16^{*}$ & $-.23^{*}$ \\
Rod & .09 & $.17^{*}$ & .06 & $.22^{*}$ & .09 & -.01 & $.21^{*}$ & .05 & $-.10^{*}$ & -.26 \\
$\begin{array}{l}\text { Prosjek } \\
\text { ocjena }\end{array}$ & $.20^{*}$ & $.23^{*}$ & $-.36^{*}$ & $.24^{*}$ & -.08 & $-.13^{*}$ & .08 & $.28^{*}$ & .12 & $.23^{*}$ \\
$\begin{array}{l}\text { Zadovoljstvo } \\
\text { školom }\end{array}$ & $.22^{*}$ & $.18^{*}$ & -.02 & $.20^{*}$ & -.04 & $-.19^{*}$ & $.19^{*}$ & $.18^{*}$ & .03 & $.11^{*}$ \\
\hline
\end{tabular}

Napomena: MKK - Ciklus (meta)kognitivne kontrole učenja; DKP - Duboko kognitivno procesiranje; PKP - Površinsko kognitivno procesiranje; SSŠN 1 - Suočavanje usmjereno na problem; SSŠN 2 Zaštita emocija udaljavanjem; SSŠN 3 - Zaštita ega udaljavanjem; TSP 1 - Traženje emocionalne i instrumentalne podrške od prijatelja; TSP 2 - Traženje emocionalne i instrumentalne podrške od roditelja; TSP 3 - Traženje emocionalne podrške od nastavnika; TSP 4 - Traženje instrumentalne podrške od nastavnika. ${ }^{*} p<.05$. 
Iz Tablice 3. vidi se da je između dobi, roda, objektivnoga i subjektivnoga školskog uspjeha te niza strategija učenja i suočavanja sa školskim neuspjehom niska statistički značajna povezanost. Najviše pozitivne povezanosti dobivene su između prosjeka ocjena i korištenja strategija DKP-a, Suočavanja usmjerenoga na problem, Traženja emocionalne i instrumentalne podrške od roditelja te između zadovoljstva školom i korištenja strategija MKK-a, Suočavanja usmjerenoga na problem i Traženja emocionalne i instrumentalne podrške od prijatelja. Ženski rod učenika pozitivno je povezan s korištenjem strategija DKP-a, Suočavanja usmjerenoga na problem te Traženja emocionalne i instrumentalne podrške od prijatelja. Dob učenika je najviše negativno povezana s korištenjem strategija MKK-a, Suočavanja usmjerenoga na problem te Traženja emocionalne $\mathrm{i}$ instrumentalne podrške od roditelja, a najviše pozitivno povezana s korištenjem Zaštite ega udaljavanjem.

Tablica 4.

Koeficijenti korelacija između osobina ličnosti učenika i strategija samoregulacije učenja (korištenja (meta)kognitivnih strategija učenja, strategija suočavanja sa školskim neuspjehom i strategija traženja socijalne podrške)

\begin{tabular}{lcccccccccc}
\hline Varijable & MKK & DKP & PKP & SSŠN 1 & SSŠN 2 & SSŠN 3 & TSP 1 & TSP 2 & TSP 3 & TSP 4 \\
\hline Otvorenost & $.27^{*}$ & $.44^{*}$ & $-.16^{*}$ & $.32^{*}$ & $.16^{*}$ & .03 & $.17^{*}$ & $.23^{*}$ & .05 & $.21^{*}$ \\
Savjesnost & $.27^{*}$ & $.32^{*}$ & $-.18^{*}$ & $.30^{*}$ & -.06 & $-.19^{*}$ & .04 & $.23^{*}$ & .00 & $.21^{*}$ \\
Neuroticizam & -.04 & $-.11^{*}$ & $.12^{*}$ & .02 & $.18^{*}$ & $.10^{*}$ & .03 & $-.11^{*}$ & .04 & $-.12^{*}$ \\
Ekstraverzija & $.26^{*}$ & $.21^{*}$ & -.06 & $.30^{*}$ & $.12^{*}$ & .07 & $.13^{*}$ & $.13^{*}$ & $.10^{*}$ & $.17^{*}$ \\
Ugodnost & $.12^{*}$ & $.21^{*}$ & -.06 & $.18^{*}$ & .05 & $-.13^{*}$ & $.18^{*}$ & $.31^{*}$ & .02 & $.22^{*}$ \\
\hline
\end{tabular}

Napomena: MKK - Ciklus (meta)kognitivne kontrole učenja; DKP - Duboko kognitivno procesiranje; PKP - Površinsko kognitivno procesiranje; SSŠN 1 - Suočavanje usmjereno na problem; SSŠN 2 Zaštita emocija udaljavanjem; SSŠN 3 - Zaštita ega udaljavanjem; TSP 1 - Traženje emocionalne i instrumentalne podrške od prijatelja; TSP 2 - Traženje emocionalne i instrumentalne podrške od roditelja; TSP 3 - Traženje emocionalne podrške od nastavnika; TSP 4 - Traženje instrumentalne podrške od nastavnika. ${ }^{*} p<.05$.

Iz Tablice 4. vidi se da su povezanosti između osobina ličnosti i strategija samoregulacije učenja statistički značajne i niske. Otvorenost je najviše pozitivno povezana s korištenjem strategija DKP-a, Suočavanja usmjerenoga na problem te Traženja emocionalne i instrumentalne podrške od roditelja, a negativno s korištenjem strategija PKP-a. Savjesnost je najviše pozitivno povezana s korištenjem strategija DKP-a, Suočavanja usmjerenoga na problem te Traženja emocionalne i instrumentalne podrške od roditelja, a negativno s korištenjem strategija Zaštite ega udaljavanjem. Neuroticizam je najviše pozitivno povezan $s$ korištenjem strategija PKP-a i Zaštite emocija udaljavanjem, a negativno s korištenjem strategija DKP-a i Traženja instrumentalne podrške od nastavnika. Ekstraverzija je najviše pozitivno povezana s korištenjem strategija MKK-a, Suočavanja usmjerenoga na problem te Traženja instrumentalne podrške od nastavnika. Ugodnost je najviše pozitivno povezana s korištenjem strategija DKP-a, Suočavanja usmjerenoga na problem te 
Traženja emocionalne $\mathrm{i}$ instrumentalne podrške od roditelja, a negativno $\mathrm{s}$ korištenjem strategije Zaštite ega udaljavanjem.

\section{Hijerarhijska regresijska analiza}

Kako bi se provjerio doprinos pojedinih mjerenih varijabli objašnjenju objektivnoga i subjektivnoga školskog uspjeha učenika, provedena je hijerarhijska regresijska analiza (Tablica 5.). U HRA-u najprije su uvedene demografske karakteristike učenika, potom osobine ličnosti, a zatim strategije samoregulacije učenja. Na taj je način omogućeno otkrivanje zasebnih doprinosa pojedinih skupina prediktora u objašnjenju varijabiliteta objektivnoga i subjektivnoga školskog uspjeha.

Tablica 5.

Rezultati hijerarhijske regresijske analize za objektivan i subjektivan školski uspjeh kao kriterija te dobi, roda, osobina ličnosti i strategija samoregulacije učenja kao prediktora

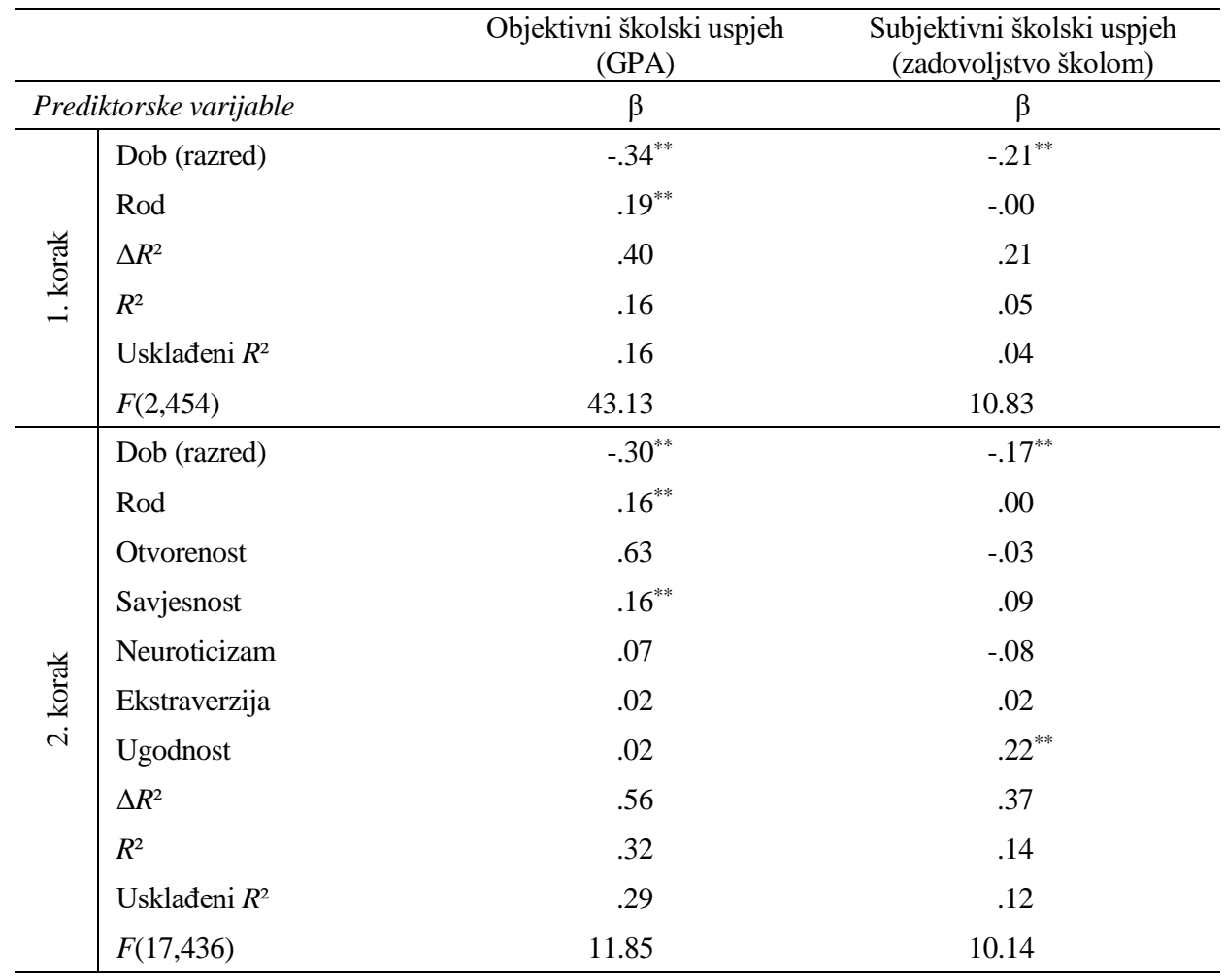




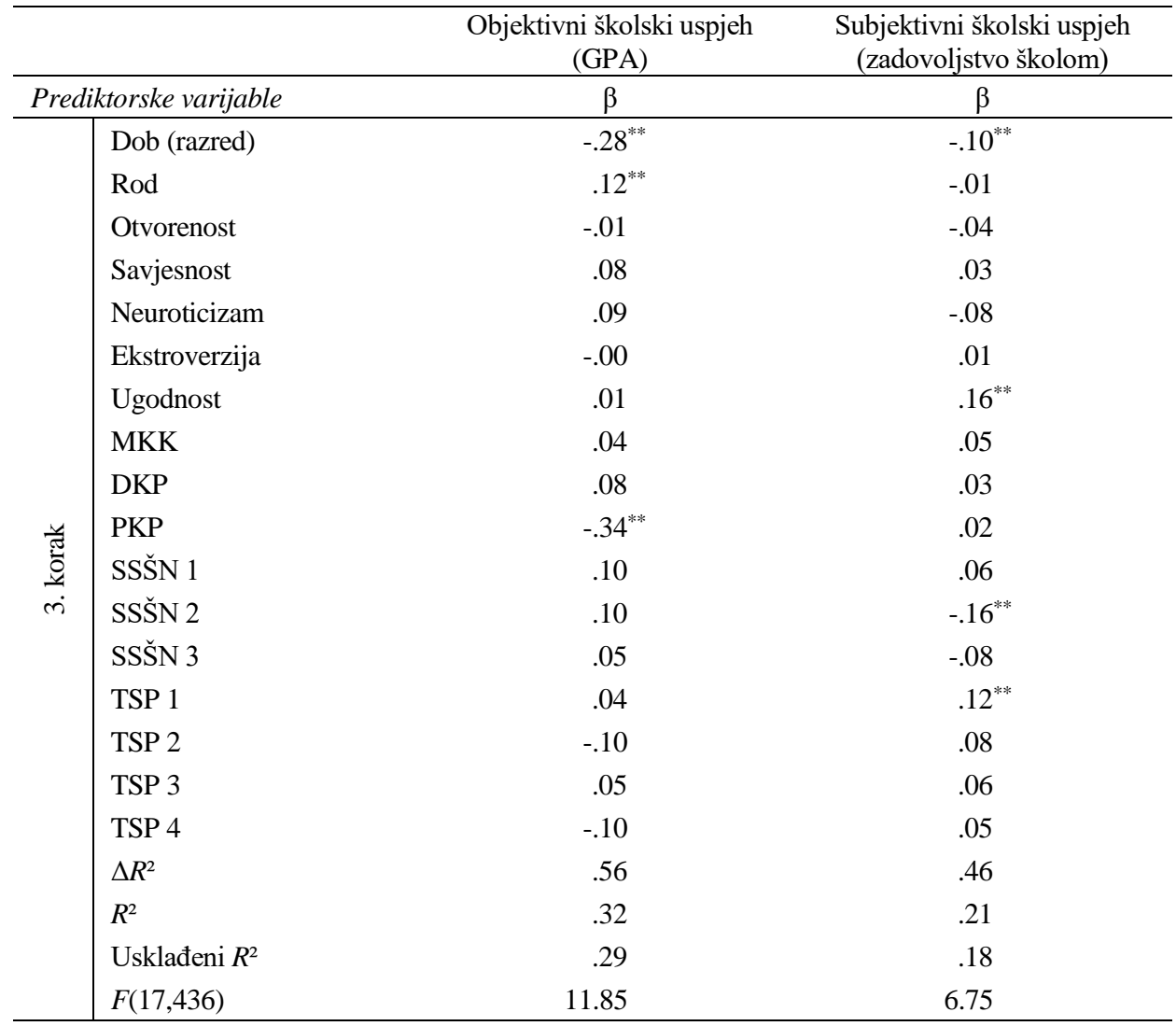

Napomena: MKK - Ciklus (meta)kognitivne kontrole učenja; DKP - Duboko kognitivno procesiranje; PKP - Površinsko kognitivno procesiranje; SSŠN 1 - Suočavanje usmjereno na problem; SSŠN 2 Zaštita emocija udaljavanjem; SSŠN 3 - Zaštita ega udaljavanjem; TSP 1 - Traženje emocionalne i instrumentalne podrške od prijatelja; TSP 2 - Traženje emocionalne i instrumentalne podrške od roditelja; TSP 3 - Traženje emocionalne podrške od nastavnika; TSP 4 - Traženje instrumentalne podrške od nastavnika. ${ }^{* *} p<.01$.

U prvom su se koraku HRA-e kao značajni prediktori objektivnoga školskog uspjeha (GPA) pokazale obje demografske varijable te je objašnjeno $16 \%$ varijance kriterija. Preciznije, mlađi učenici $(\beta=-.34)$ i učenice $(\beta=.19)$ imaju viši GPA. Uvođenjem osobina ličnosti kao prediktora u drugome koraku postotak objašnjene varijance kriterija značajno se povećao (za $13 \%$ ), a od prethodno navedenih značajnih prediktora ni jedan nije izgubio značajnost. U tome je koraku osobina Savjesnost pozitivni prediktor $(\beta=.16)$, što znači da je viša razina savjesnosti kod učenika značajan prediktor boljega GPA-a. Među strategijama samoregulacije učenja u trećemu su se koraku dob i rod i nadalje pokazali značajnim prediktorima, za razliku od savjesnosti, te je PKP kao jedina kognitivna strategija učenja značajan negativni prediktor GPA-a $(\beta=-.34)$. 
U prvome se koraku HRA-e kao značajni negativni prediktor subjektivnoga školskog uspjeha pokazala jedino demografska varijabla dob te je objašnjeno $4 \%$ varijance kriterija. Preciznije, mlađi učenici $(\beta=-.21)$ imaju veće zadovoljstvo školom.

Uvođenjem osobina ličnosti kao prediktora u drugome koraku postotak objašnjene varijance kriterija značajno se povećao (za $8 \%$ ), a prethodno navedeni značajni prediktor nije izgubio značajnost. U tome je koraku osobina Ugodnost značajan pozitivni prediktor $(\beta=.22)$, što znači da učenici koji su viši na toj osobini iskazuju veće zadovoljstvo školom. Od strategija samoregulacije učenja u trećemu koraku strategija Zaštite emocija udaljavanjem značajan je negativni prediktor ( $\beta=$ -.16), a strategija Traženja emocionalne i instrumentalne podrške od prijatelja značajan je pozitivni prediktor $(\beta=.12)$ i ta skupina prediktora značajno pridonosi postotku objašnjene varijance subjektivnoga školskog uspjeha (dodatnih $6 \%$ ). Učenici koji manje koriste strategije Zaštite emocija udaljavanjem kada se suočavaju sa školskim neuspjehom te učenici koji više koriste strategije Traženja emocionalne i instrumentalne podrške od prijatelja iskazuju veće zadovoljstvo školom.

S obzirom na to da su rezultati HRA-e osjetljivi na interkorelacije prediktora, može doći do promjena u značajnosti pojedinih prediktora uslijed uvođenja nove skupine varijabli. Smanjenje učinka u zadnjemu koraku mjerenih prediktora može sugerirati i neke posredne učinke varijabli koje nisu bile predmetom ovoga istraživanja. Završni korak HRA-e za objektivni školski uspjeh kao kriterij upućuje na značajan doprinos dobi (razreda), roda i kognitivnih strategija PKP-a, a ukupno je zadanim skupovima prediktorskih varijabli objašnjeno $29 \%$ varijance toga kriterija. Završni korak HRA-e za subjektivni školski uspjeh kao kriterij upućuje na značajan doprinos dobi, osobine Ugodnosti, strategija Zaštite emocija udaljavanjem te Traženja emocionalne i instrumentalne podrške od prijatelja, a ukupno je zadanim skupovima prediktorskih varijabli objašnjeno $18 \%$ varijance toga kriterija. Zaključno, mlađi učenici, učenice i oni koji manje koriste kognitivnu strategiju PKP ostvaruju bolji GPA. Mlađi učenici, s razvijenijom osobinom Ugodnosti, koji manje koriste strategiju Zaštite emocija udaljavanjem prilikom suočavanja sa školskim neuspjehom, a više strategiju Traženja emocionalne i instrumentalne podrške od prijatelja, ostvaruju bolji subjektivni školski uspjeh.

\section{Rasprava}

S obzirom da su dosadašnja istraživanja ukazivala na nejednoznačne nalaze povezanosti osobina ličnosti i samoregulacijskih strategija učenja koji pridonose boljoj školskoj i socijalnoj prilagodbi učenika, cilj je ovoga istraživanja bio ispitati u kojoj mjeri osobine ličnosti, (meta)kognitivne strategije učenja, strategije suočavanja sa školskim neuspjehom i strategije traženja socijalne podrške te dob i rod učenika objašnjavaju objektivni i subjektivni školski uspjeh. Dobivene korelacije u ovome 
istraživanju upućuju na značajnu povezanost mjerenih demografskih varijabli učenika (dob i rod), osobina ličnosti, kao i niza samoregulacijskih strategija učenja s objektivnim i subjektivnim školskim uspjehom, što je u skladu s brojnim istraživanjima (Bidjerano i Dai, 2007; Lounsbury i sur., 2009). Međutim, provjera zasebne uloge pojedinih varijabli, primjenom HRA-e, upućuje na značajne doprinose samo nekih varijabli. Preciznije, rezultati ukazuju da objektivnomu školskom uspjehu doprinosi mlađa dob učenika, ženski rod, manje korištenje kognitivne strategije PKP-a te u drugome koraku i Savjesnost. Subjektivnomu školskom uspjehu doprinosi mlađa dob učenika, razvijenija Ugodnost, manje korištenje strategije Zaštite emocija udaljavanjem prilikom suočavanja sa školskim neuspjehom te veće korištenje strategije Traženja emocionalne i instrumentalne socijalne podrške od prijatelja. Razmatranjem doprinosa dobi (razreda) u ovome istraživanju utvrđeno je da mlađi učenici ostvaruju bolji objektivni i subjektivni školski uspjeh, čime su potvrđeni rezultati ranijih istraživanja (Lončarić, 2010; Pavić, 2015). To se objašnjava njihovim individualnim karakteristikama: većom motivacijom za postignućem, pozitivnijim stavovima prema školi, većom privrženošću školi i predanosti učenju, sklonošću pozitivnijim emocijama veznima za objekte i događaje u školskome okruženju, većom znatiželjom, upornošću i energijom prilikom dostizanja školskih ciljeva (Macuka i Burić, 2015), pozitivnijom slikom o sebi i višim samopoštovanjem (Grgantov, 2010; Nikčević-Milković i sur., 2014), višom emocionalnom i školskom samoefikasnošću (Grgantov, 2010), manjim intenzitetom školskoga stresa, većim interesima za školske aktivnosti i sustavom vrijednosti u kojima školsko postignuće ima značajno mjesto (Lončarić, 2010) te vanjskim faktorima vezanima za obitelj, razred, školu i društvo u cjelini (npr. mlađi su učenici zadovoljniji svim aspektima razredno-nastavnoga ozračja, veća je razredna kohezija, socijalna potpora). Gillet i suradnici (2012) navode da s dobi učenika dolazi do pada intrinzične i ekstrinzične motivacije za školsko postignuće. Taj se pad događa oko trinaeste godine, potom slijedi stagnacija, a onda povećanje motivacije nakon šesnaeste godine, što upućuje na pubertetske promjene, a potom ponovnu stabilizaciju ličnosti tijekom adolescencije (Gottfried i sur., 2001). Prema Lončariću (2010) stariji su učenici više usmjereni na pokazivanje znanja i vještina te neškolske ciljeve, a što se onda odražava na smanjenje školskoga uspjeha. Prelaskom učenika iz razvojnoga perioda srednjega djetinjstva u adolescentski razvojni period školska samoefikasnost opada, a motivaciju za školskim postignućem zamjenjuju neki drugi interesi koji adolescentima postaju zanimljiviji i izazovniji. Razmatranjem doprinosa roda učenika u ovome je istraživanju utvrđeno da učenice imaju bolji GPA od učenika, što je u skladu s brojnim nalazima ranijih istraživanja. Prema Macuki i Burić (2015) bolji uspjeh učenica objašnjava se razlikom u motivaciji, angažiranosti, ustrajnosti, socijalnoj potpori i sl. Učenice su obično upornije (Kenney-Benson i sur., 2006), sklonije su tražiti pomoć (Ryan i sur., 2009), posjeduju više razine samokontrole (Carvalho, 2016), njihovo je učenje općenito više samoregulirano (Šimić Šašić i Sorić, 2011) te su angažiranije u nastavi (Vecchione i sur., 2014). Također, učenice u odnosu na svoje muške kolege pokazuju višu razinu 
samoefikasnosti, veće zadovoljstvo školom, veće povjerenje u nastavnike te odnose s nastavnicima procjenjuju boljima (Koludrović i Radnić, 2013). Kod učenica su ciljne orijentacije učenja više usmjerene na usvajanje znanja i vještina te su učenice više usmjerene na socijalne odnose, za razliku od učenika koji su više usmjereni na izvedbu i ekstrinzične ciljeve (Koludrović i Reić-Ercegovac, 2014). Ciljne orijentacije učenja kod učenika više su usmjerene i na izbjegavanje truda, oni više koriste strategije učenja temeljene na mehaničkome učenju i zapamćivanju, imaju višu emocionalnu, a nižu školsku samoefikasnost, više vjeruju da su sredstva za postizanje uspjeha internalna (zalaganje i sposobnosti) $\mathrm{u}$ odnosu na učenice koje više vrednuju i više su orijentirane na učenje pa zbog toga više koriste strategije organiziranja i praćenja vlastitoga učenja te strategije ovladavanja emocijama (Šimić Šašić i Sorić, 2011). Uslijed većega GPA-a i bolje prilagođenosti škole učenicama one su i zadovoljnije školom (Verkuyten i Thijs, 2002). Međutim, Jokić i Ristić Dedić (2010) navode da se generalizirajući različite međunarodne znanstvene spoznaje može utvrditi da učenice postižu viša obrazovna postignuća iskazana školskim ocjenama, dok u slučajevima kada je obrazovno postignuće iskazano rezultatom na vanjskome vrednovanju rodne razlike ovise o ispitivanome području i dobi učenika (Duckworth i Seligman, 2006). Učenice postižu viša obrazovna postignuća iskazana školskim ocjenama u svim predmetima, uključujući matematiku i prirodne znanosti, od prvoga razreda osnovne škole pa do visokoškolske razine. U slučaju vanjskoga vrednovanja nalazi nisu toliko jednoznačni jer različita međunarodna ispitivanja znanja, vještina i sposobnosti pokazuju da učenici postižu više rezultate na standardiziranim ispitivanjima iz područja matematike, dok učenice postižu bolje obrazovne rezultate $u$ ispitivanjima čitanja i jezika općenito (Baker i Jones, 1993; Beller i Gafni, 1996; Marks, 2007). Manje korištenje maladaptivne kognitivne strategije PKP u ovome se istraživanju pokazalo najznačajnim negativnim prediktorom GPA-a, što je u skladu s brojnim nalazima ranijih istraživanja (Coutinho i Neuman, 2008; Diseth i Kobbeltvedt, 2010; Lončarić, 2014; Matić i Marušić, 2016; Schwinger i sur., 2009). Coutinho i Neuman (2008) navode da površinski pristup učenju rezultira pamćenjem i ponavljanjem činjenica, a ne dovodi do razumijevanja prave prirode informacija. Učenici koji koriste PKP uče napamet i bez razumijevanja, što dovodi do niže kvalitete svih ishoda učenja (Lončarić, 2014). Za uspješne ishode učenja uz DKP važni su i metakognitivni procesi jer dovode do konceptualnih promjena u učenju, što omogućuje duže zadržavanje materijala i njegovu primjenu na nov način (Georghiades, 2000). Matić i Marušić (2016) također navode da učenici odličnoga školskog uspjeha rjeđe pribjegavaju defanzivnim strategijama PKP-a, a češće koriste metakognitivne strategije učenja. Pintrich (1999) i Sorić (2014) također naglašavaju razliku u ishodima učenja kada učenici koriste efikasne kognitivne strategije učenja (poput elaboracije ili organizacije materijala za učenje) koje potiču duboko procesiranje i rezultiraju dubljim razumijevanjem onoga što se uči. Čini se da primjena strategija koje potiču dubinski pristup učenju omogućuje postizanje boljega uspjeha u duljemu vremenskom razdoblju, premda pojedini autori upozoravaju da dosadašnji empirijski 
dokazi u tome smislu nisu jednoznačni (Murayama i sur., 2013). Primjerice, Diseth i Martinsen (2003) te Vrdoljak i suradnici (2014) nalaze kako korištenje DKP-a ne pridonosi značajnomu predviđanju školskoga uspjeha. Iako smo ovim istraživanjem predvidjeli da će korištenje adaptivnih strategija učenja i suočavanja sa školskim neuspjehom pridonijeti boljemu GPA-u, nalazi to nisu potvdili te se s pravom pitamo zašto. Najprije se, kada se pogleda tablica korelacija (Tablica 3.), može uočiti da je povezanost između navedenih adaptivnih samoregulacijskih strategija i objektivnoga školskog uspjeha (kao i onoga subjektivnog) značajna, ali ipak niska. Odgovor vjerojatno možemo potražiti u nalazima koji ukazuju na mnogobrojne probleme koje učenici imaju u hrvatskim školama, naročito srednjima. Iako se u školama potiče stjecanje znanja, učenici su preopterećeni obvezama zbog neprimjerenih školskih programa, nastavnici više potiču niže, a manje više razine znanja te nedostatno podržavaju učenike u njihovu procesu rasta i razvoja, sustav je ocjenjivanja nerazvijen i često nepravedan, obrazovni zahtjevi nisu usklađeni sa zakonitostima ljudskoga razvoja i rezultatima istraživanja iz područja učenja, ljudskoga razvoja, motivacije i sl. Posljedice su toga da učenici često imaju destruktivan osjećaj nekompetentnosti za učenje i strah od škole, kao i nezadovoljstvo školom i nastavnicima (Bezinović i Ristić Dedić, 2004). S druge strane, znanje učenika često se ispituje zadatcima višestrukoga izbora koji uglavnom ispituju površinsko učenje materijala, a ne dublje razumijevanje i kritički pristup sadržaju (Senko i sur., 2008). Čak i prirodne znanosti, koje zahtijevaju konceptualno znanje koje podrazumijeva nalaženje novih funkcionalnih veza među pojmovima, imaju veliki broj rutinskih zadataka za čije je rješavanje potrebno proceduralno znanje (Vrdoljak i VlahovićŠtetić, 2018). Uslijed svega toga čini se da adaptivne strategije učenja i suočavanja sa školskim neuspjehom nisu uvijek nužne kako bi učenik „preživio“ školsku svakodnevicu i bio uspješan u hrvatskim školama. Važno je spomenuti i Savjesnost kao značajni prediktor GPA-a, koji je utvrđen u drugome koraku HRA-e, a u konačnome koraku nije. Utvrđeni rezultat na tome uzorku ukazuje na to da prediktorski doprinos te osobine ličnosti, premda su prethodna istraživanja (kao i korelacijska analiza u ovome istraživanju) ukazala na njegovu značajnost, postoji, no ne u dovoljnoj mjeri da bi „nadjačao“ interkorelacije koje pokazuje sa strategijama samoregulacije učenja. Morosanova i suradnici (2018) navode da su strategije samoregulacije učenja integrativni kognitivno-interpersonalni konstrukt jer istovremeno predstavljaju kognitivni sistem procesiranja informacija, kao i specifičnost instrumentalnih značajki koje regulira ličnost. Stoga bi bilo zanimljivo u budućim istraživanjima analizirati parcijalne korelacije i zasebne doprinose Savjesnosti i strategija samoregulacije učenja.

U istraživanju se pokazalo kako veće zadovoljstvo školom imaju učenici koji više koriste adaptivne strategije Traženja emocionalne i instrumentalne podrške od prijatelja te koji manje koriste maladaptivne strategije Zaštite emocija udaljavanjem. Potonju strategiju karakterizira izbjegavanje situacije koja je dovela do školskoga neuspjeha, maštanje, skretanje pažnje od izvora i posljedica neuspjeha, čime učenici štite svoje samopoštovanje. Dok su mlađi učenici skloniji tražiti pomoć od roditelja 
kad su neuspješni u školi, traženje emocionalne i instrumentalne podrške od prijatelja postaje sve važnije i kontinuirano raste s dobi (Seiffge-Krenke, 1993). Greenglass (1993) navodi da mreže socijalne podrške upravo služe kao zaštitni čimbenik u procesu suočavanja i izravno poboljšavaju dobrobit pojedinca. Sudionici u ovome istraživanju učenici su mlađega i srednjega razvojnog perioda adolescencije za koji je karakteristično da vršnjački odnosi postaju sve važniji i intenzivniji te da im vršnjaci čine važan izvor socijalne podrške. U tome razvojnom periodu adolescenti formiraju i vlastiti identitet te mnogi pribjegavaju maštanju i skretanju pažnje od izvora koji ih čine neuspješnima. Dakle, što učenici manje koriste maladaptivnu strategiju Zaštite emocija udaljavanjem, a više koriste adaptivnu strategiju Traženja podrške od vršnjaka, njihovo je zadovoljstvo školom, u kojoj primarno ostvaruju socijalizaciju, veće. Bubić i Goreta (2015) navode da razmatranje zadovoljstva školom ne smije uključivati samo školska postignuća već i dodatne često zanemarivane činitelje, primjerice, način na koji učenici doživljavaju sebe, svoje školske sposobnosti i socijalne vještine, kao i socijalno okruženje.

Iako se pretpostavljalo, na temelju ranijih istraživanja, da će savjesniji (Cazan i Schiopca, 2014; Chamorro-Premuzic i Furnham, 2009; Furnham i sur., 2003; Komarraju i sur., 2011; Matešić i sur., 2009; Mishra, 1997; Mõttus i sur., 2006; Poropat, 2009), otvoreniji (Blickle, 1996; Cazan i Schiopca, 2014; Hakim i sur., 2018; Mõttus i sur., 2006), ekstravertiraniji (De Raad i Schouwenburg, 1996), emocionalno stabilniji (De Raad i Schouwenburg, 1996; Furnham i sur., 2003; Hakim i sur., 2018) i ugodniji (Komarraju i sur., 2011; Mõttus i sur., 2006; Poropat, 2009) učenici imati veći objektivni i subjektivni školski uspjeh, u ovome se istraživanju jedino osobina Savjesnost pokazala značajnim pozitivnim prediktorom GPA-a u drugome koraku HRA-e. Ta se osobina u istraživanjima dosljedno pokazuje značajnom u predviđanju školskoga uspjeha, posebno na višim razinama obrazovanja, kada su osobine poput ustrajnosti, samokontrole i težnje za postignućem najvažnije (Chamorro-Premuzic i Furnham, 2009). Međutim, uvođenjem samoregulacijskih strategija u završnome koraku HRA-e gubi se doprinos te osobine objektivnomu školskom uspjehu. Uvođenjem strategija samoregulacije učenja osobina Savjesnost prestaje biti značajan prediktor, što može ukazivati da su strategije posredujuće varijable objašnjenju povezanosti osobina ličnosti i GPA-a. Osobina Ugodnost pokazala se značajnim pozitivnim prediktorom subjektivnoga školskog uspjeha. Matešić i suradnici (2009) navode da učenici viših rezultata na toj osobini imaju niži GPA zbog održavanja široke mreže prijatelja, zbog čega se pojavljuje nedostatak vremena za učenje. Možda su upravo zbog važnosti socijalnih odnosa ti učenici zadovoljniji školom jer u njoj ostvaruju socijalne ciljeve koji su im primarno važni. Osobina ugodnosti povezana je s većim poštivanjem uputa nastavnika, trudom i ustrajnošću (Vermetten i sur., 2001), u čemu leži dio objašnjenja većega zadovoljstva školom tih učenika. Na bivarijatnoj razini rezultata vidi se da je osobina ugodnosti učenika značajno povezana $s$ traženjem veće emocionalne $i$ instrumentalne podrške od prijatelja i roditelja te s traženjem veće instrumentalne podrške od nastavnika, čime se potvrđuje veća socijalna usmjerenost tih učenika. 
Vezano uz nalaz da su različite osobine ličnosti značajni prediktori GPA-a (savjesnost) i subjektivnoga školskog uspjeha (ugodnost), poznato je da objektivni i subjektivni školski uspjeh ne moraju nužno biti u pozitivnoj korelaciji te da učenik koji ima izvrstan objektivni školski uspjeh može i ne mora biti zadovoljan školom, i obrnuto. Samim time, s obzirom je riječ o dvjema nezavisnim varijablama, jer je prva više vezana uz sposobnosti/kompetencije (ili bi barem trebala biti), a druga uz odnose, logično je da će se onda uz njih vezati i drugačije osobine ličnosti.

Ovo istraživanje ima svoje nedostatke i ograničenja. U istraživanju su korištene isključivo mjere samoprocjena, što osim problema zajedničke varijance uvjetovane metodom nosi i rizik postojanja iskrivljenih i socijalno poželjnih odgovora. Uzorak, raspon dobi te broj škola trebao bi biti veći kako bi rezultati bili sigurniji za generalizaciju. Rezultati se temelje na korelacijama, čime je onemogućeno zaključivanje o uzročno-posljedičnim vezama između ispitivanih varijabli, kao i priroda korištenih podataka koji su u ovome istraživanju transverzalni. Iako ovo istraživanje potvrđuje povezanost osobina ličnosti, strategija samoreguliranoga učenja i školskoga postignuća, korelacije među varijablama uglavnom su niske, a samo neke osobine ličnosti i strategije pridonijele su objašnjenju varijance školskoga uspjeha, što upućuje na potrebu daljnjih istraživanja suodnosa tih varijabli. Uz set ispitivanih skupina prediktora koji su uspješno objasnili $29 \%$ objektivnoga i $18 \%$ subjektivnoga školskog uspjeha, značajan je dio varijance obiju kriterijskih varijabli ipak ostao neobjašnjen. To upućuje na potrebu daljnjih istraživanja tih odrednica, ali također pokazuje kako je potrebno istraživati i druge odrednice školskoga uspjeha (osobne i okolinske) koje su možda u većoj mjeri povezane s tim konstruktima. Trebalo bi provjeriti i koji bi prediktori pridonosili školskomu uspjehu kada bi se dobne skupine promatrale odvojeno. Ovo istraživanje upućuje i na moguće nedostatke našega obrazovnog sustava (nedostatak doprinosa adaptivnih strategija samoregulacije učenja, što je usko povezano s razvojem onih osobina ličnosti koje su značajno povezane sa školskim uspjehom; nedostatak vezan uz pitanje objektivnoga školskog uspjeha, odnosno ocjenjivanja kao mjerila učenikovih kompetencija). Takva su istraživanja nužna za poboljšanje kvalitete rada u odgojnoobrazovnome sustavu jer mogu ponuditi praktične smjernice za kreiranje obrazovnih programa usmjerenih na poboljšanje GPA-a i učeničkoga zadovoljstva školom. Programi poučavanja i uvježbavanja samoregulacijskih strategija $\mathrm{s}$ ciljem efikasnijega učenja i pamćenja općenito te efikasnijega svladavanja gradiva pojedinih školskih predmeta već su dobro poznati i korisni učenicima različite dobi. Jedno od glavnih usmjerenja istraživača od 60-ih godina 20. stoljeća bio je i nizak školski uspjeh sposobnih učenika. Prema utvrđenim osobinama ličnosti učenika mogu se predvidjeti njihovi lošiji uspjesi te ih se može što prije usmjeriti na programe pomoći. Nastavne metode mogu se prilagođavati specifičnim osobinama ličnosti učenika, što ide u smjeru veće individualizacije nastavnoga procesa. Međutim, odgojno-obrazovni praktičari moraju uzimati u obzir moderatorske utjecaje dobi prilikom procjene povezanosti osobina ličnosti sa školskom izvedbom (na osnovnoškolskoj razini s povećanjem dobi povećava se povezanost između GPA-a i 
Savjesnosti, Emocionalne stabilnosti i Ekstraverzije, a povezanost s Otvorenošću se smanjuje; na srednjoškolskoj razini s povećanjem dobi dolazi do pada povezanosti GPA-a s Ugodnošću, Emocionalnom stabilnošću i Otvorenošću) (Poropat, 2009). Zbog maloga broja sličnih istraživanja u Republici Hrvatskoj ovaj rad predstavlja doprinos razumijevanju značaja ispitivanih prediktora školskoga uspjeha, što implicira usmjeravanje većega fokusa na njih tijekom odgojno-obrazovnoga procesa.

\section{Literatura}

Baker, D. i Jones, P. (1993). Creating gender equality: Cross-national gender stratification and mathematical performance. Sociology of Education, 66(2), 91-103. https://doi.org/ $10.2307 / 2112795$

Barrick, M. R., Mount, M. K. i Strauss, J. P. (1993). Conscientiousness and performance of sales representatives: Test of the mediating effects of goal setting. Journal of Applied Psychology, 78(5), 715-722. https://doi.org/10.1037/0021-9010.78.5.715

Beller, M. i Gafni, N. (1996). The 1991 international assessment of educational progress in mathematics and sciences: The gender differences perspective. Journal of Educational Psychology, 88(2), 365-377. https://doi.org/10.1037/0022-0663.88.2.365

Benet-Martinez, V. i John, O. P. (1998). Los Cinco Grandes across cultures and ethnic groups: Multi-trait multi-method analyses of the Big Five in Spanish and English. Journal of Personality and Social Psychology, 75(3), 729-750.

Bezinović, P. i Ristić Dedić, Z. (2004). Škola iz perspektive učenika: Smjernice za promjene. Institut za društvena istraživanja u Zagrebu, Centar za istraživanje i razvoj obrazovanja. Preuzeto s https://www.idi.hr/drzavnamatura/dokumenti/skola_iz_perspektive_ ucenika.pdf\%20

Bidjerano, T. i Dai, D. (2007). The relationship between the big-five model of personality and self-regulated learning strategies. Learning and Individual Diferencies, 17(1), 69-81. https://doi.org/10.1016/j.lindif.2007.02.001

Blickle, G. (1996). Personality traits, learning strategies and performance. European Journal of Personality, 10(5), 337-352. https//doi.org/10.1002/(SICI)1099-0984(199612)10: 5<337::AID-PER258>3.0.CO;2-7

Brdar, I., Rijavec, M. i Lončarić, D. (2006). Goal orientations, coping with school failure and school achievement. European Journal of Psychology of Education, 21(1), 53-70. https://doi.org/10.1007/BF03173569

Bubić, A. i Goreta, I. (2015). Akademske i socijalne odrednice općeg zadovoljstva školom. Psihologijske teme, 24(3), 473-493.

Caprara, G. V., Vecchione, M., Alessandri, G., Gerbino, M. i Barbaranelli, C. (2011). The contribution of personality traits and self-efficacy beliefs to academic achievement: A longitudinal study. British Journal of Educational Psychology, 81(1), 78-96. https://doi.org/10.1348/2044-8279.002004 
Carvalho, R. G. G. (2016). Gender differences in academic achievement: The mediating role of personality. Personality and Individual Differences, 94, 54-58.

Cazan, A. M. i Schiopca, B. A. (2014). Self-directed learning, personality traits and academic achievement. Social and Behavioral Sciences, 127, 640-644. https://doi.org/10.1016/j. sbspro.2014.03.327

Chamorro-Premuzic, T. i Furnham, A. (2009). Mainly Openness: The relationship between the Big Five personality traits and learning approaches. Learning and Individual Differences, 19(4), 524-529. https://doi.org/10.1016/j.lindif.2009.06.004

Costa, P. T. Jr. i McCrae, R. R. (1985). The NEO Personality Inventory manual. Psychological Assessment Resources.

Costa, P. T. Jr. i McCrae, R. R. (1992). The revised NEO Personality Inventory (NEO-PI-R) and NEO Five Factor Inventory (NEO-FFI) professional manual. Psychological Assessment Resources. https://doi.org/10.4135/9781849200479.n9

Coutinho, S. A. i Neuman, G. (2008). A model of metacognition, achievement goal orientation, learning style and self-efficacy. Learning Environments Research, 11(2), 131-151.

De Anda, D., Baroni, S., Boskin, L., Buchwald, L., Morgan, J., Ow, J., Siegel Gold, J. i Weiss, R. (2000). Stress, stressors and coping among high school students. Children and Youth Services Review, 22(6), 441-463. https://doi.org/10.1016/S0190-7409(00)00096-7

De Raad, B. i Schouwenburg, H. C. (1996). Personality in learning and education: A review. European Journal of Personality, 10(5), 303-336. https://doi.org/10.1002/(SICI)10990984(199612)10:5<303::AID-PER262>3.0.CO;2-2

Diseth, Å. i Kobbeltvedt, T. (2010). A mediation analysis of achievement motives, goals, learning strategies, and academic achievement. British Journal of Educational Psychology, 80(4), 671-687. https://doi.org/10.1348/000709910X492432

Diseth, Å. i Martinsen, Ø. (2003). Approaches to learning, cognitive style, and motives as predictors of academic achievement. Educational Psychology, 23(2), 195-207. https://doi.org/10.1080/01443410303225

Duckworth, A. i Seligman M. (2006). Self-discipline gives girls the edge: Gender in selfdiscipline, grades, and achievement test scores. Journal of Educational Psychology, 98(1), 198-208. https://doi:10.1037/0022-0663.98.1.198

Eccles, J. S., Wigfield, A., Flanagan, C., Miller, C., Reuman, D. i Yee, D. (1989). Self-concepts, domain values, and self-esteem: Relations and changes at early adolescence. Journal of Personality, 57, 283-310. https://doi.org/10.1111/j.1467-6494.1989.tb00484.x

Eysenck, M. W. i Van Berkum, J. (1992). Trait anxiety, defensiveness, and the structure of worry. Personality and Individual Differences, 13(12), 1285-1290. https://doi.org/10. 1016/0191-8869(92)90170-T

Furnham, A., Chamorro-Premuzic, T. i McDougall, F. (2003). Personality, cognitive ability, and beliefs about intelligence as predictors of academic performance. Learning and Individual Differences, 14(1), 49-66. https://doi:10.1016/j.lindif.2003.08.002 
Garcia, T. i Pintrich, P. R. (1994). Regulating motivation and cognition in the classroom: The role of self-schemas and self-regulatory strategies. U: D. H. Schunk i B. J. Zimmerman (Ur.), Self-regulation of learning and performance: Issues and educational applications (str. 127-153). Lawrence Erlbaum Associates.

Georghiades, P. (2000). Beyond conceptual change learning in science education: Focusing on transfer, durability and metacognition. Educational research, 42(2), 119-139. https://doi.org/10.1080/001318800363773

Gillet, N., Vallerand, R. J. i Lafreniere, M. K. (2012). Intrinsic and extrinsic school motivation as a function of age: The mediating role of autonomy support. Social Psychology of Education, 15, 77-95. https://doi.org/10.1007/s11218-011-9170-2

Gottfried, A. E., Fleming, J. S. i Gottfried, A. W. (2001). Continuity of academic intrinsic motivation from childhood through late adolescence: A longitudinal study. Journal of Educational Psychology, 93(1), 3-13. https://doi.org/10.1037/0022-0663.93.1.3

Greenglass, E. R. (1993). The contribution of social support to coping strategies. Applied Psychology, 42(4), 323-340. https://doi.org/10.1111/j.1464-0597.1993.tb00748.x

Grgantov, A. (2010). Samopoštovanje i samoefikasnost učenika s obzirom na spol, dob $i$ osobine ličnosti. [Neobjavljena doktorska disertacija]. Filozofski fakultet, Sveučilište u Splitu.

Hakim, A., Hussain, B. i Iqbal, N. M. (2018). Source traits of adolescents' personality as a predictor of their achademic achievement: A cross-sectional study. Bulletin of Education and Research, 40(1), 19-37.

Jokić, B. i Ristić Dedić, Z. (2010). Differences in educational attainment of third and seventh grade pupils in Croatia with respect to gender and parents' educational level: A population perspective. Revija za socijalnu politiku, 17(3), 345-362. https://doi.org/10. 3935/rsp.v17i3.954

Judge, T., Bono, A., Ilies, J. E., Gerhardt, R. i Megan, W. (2002). Personality and leadership. A qualitative and quantitative review. Journal of Applied Psychology, 87(4), 765-780.

Kardum, I., Gračanin, A. i Hudek-Knežević, J. (2006). Odnos crta ličnosti i stilova privrženosti s različitim aspektima seksualnosti kod žena i muškaraca. Psihologijske teme, 15(1), 101-128.

Kenney-Benson, G., Pomerantz, E. M., Ryan, A. M. i Patrick, H. (2006). Sex differences in math performance: The role of children's approach to schoolwork, Developmental Psychology, 42(1), 11-26.

Kline, R. B. (2005). Principles and practice of structural equation modeling. The Guilford Press. https://doi.org/10.1177/1049731509336986

Koludrović, M. i Radnić, I. (2013). Doprinos nekih osobnih i socijalnih čimbenika u objašnjenju školskog uspjeha u ranoj adolescenciji. Pedagogijska istraživanja, 10(1), 65-79.

Koludrović, M. i Reić Ercegovac, I. (2014). Uloga razredno-nastavnog ozračja u objašnjenju ciljnih orijentacija učenika. Društvena istraživanja: Časopis za opća društvena pitanja, 23(2), 283-302. https://doi.org/10.5559/di.23.2.04 
Komarraju, M., Karau, S. J., Schmeck, R. R. i Avdic, A. (2011). The Big Five personality traits, learning styles, and academic achievement. Personality and Individual Differences, 51(4), 472-477. https: //doi.org/10.1016/j.paid.2011.04.019

Krapić, N., Kardum, I. i Kristofić, B. (2008). Odnos crta ličnosti i sposobnosti s profesionalnim interesima. Psihologijske teme, 17(1), 75-91.

Lončarić, D. (2008). Kognitivni in motivacijski dejavniki procesov samoregulacije pri učenju in soočanju s školskim neuspehom [Kognitivni i motivacijski čimbenici procesa samoregulacije u učenju $i$ suočavanju sa školskim neuspjehom]. [Neobjavljena doktorska disertacija]. Filozofski fakultet, Sveučilište u Ljubljani.

Lončarić, D. (2010). Spol i dob kao odrednice samoreguliranog učenja za cjeloživotno obrazovanje. U: R. Bacalja (Ur.), Zbornik radova s međunarodnog znanstveno-stručnog skupa Perspektive cjeloživotnog obrazovanja učitelja $i$ odgojitelja (str. 104-118). Sveučilište u Zadru.

Lončarić, D. (2014). Motivacija i strategije samoregulacije učenja: Teorija, mjerenje $i$ primjena. Učiteljski fakultet Sveučilišta u Rijeci.

Lounsbury, J. W., Levy, J. J., Park, S., Gibson, L. W. i Smith, R. (2009). An investigation of the construct validity of the personality trait of self-directed learning. Learning and Individual Differences, 19(4), 411-418. https://doi:10.1016/j.lindif.2009.03.001

Macuka, I. i Burić, I. (2015). Školski uspjeh mlađih adolescenata: Važnost uloge osobnih i obiteljskih čimbenika. Društvena istraživanja: Časopis za opća društvena pitanja, 24(4), 487-507. https://doi.org/10.5559/di.24.4.02

Marks, G. (2007). Accounting for the gender gap in reading and mathematics: Evidence from 31 countries. Oxford Review of Education, 34(1), 1-21. https://doi.org/10.1080/ 03054980701565279

Matešić, K., Ružić, V. i Matešić, K. Jr. (2009). Odnos između osobina ličnosti mjerenih BFQ upitnikom i školskog uspjeha kod učenika gimnazije. Odgojne znanosti, 11(1), 171-181.

Matić, J. i Marušić, I. (2016). Samopoimanje i strategije učenja. Napredak, 157(3), 283-299.

Mishra, B. B. (1997). Correlates of academic achievement of high school students in India. The Journal of Education Review, 103(2), 21-25.

Morosanova, V., Bondarenko, I., Fomina, T. i Burmistrova-Savenkova, A. (2018). Selfregulation, personality factors, academic motivation, math achievement in middle and senior school. U: S. Sheridan i N. Veraksa (Ur.), The european procedings of social and behavioural sciences, XLIII (str. 401-410). VII International Conference „Early Childhood Care and Education“" (ECCE 2018) Moscow, Russia: Future Academy.

Mõttus, R., Pullmann, H. i Allik, J. (2006). Toward more readable Big Five personality inventories. European Journal of Psychological Assessment, 22(3), 149-157. https://doi.org/10.1027/1015-5759.22.3.149

Murayama, K., Pekrun, R., Lichtenfeld, S. i Vom Hofe, R. (2013). Predicting long-term growth in students' mathematics achievement: The unique contributions of motivation and cognitive strategies. Child Development, 84(4), 1475-1490. https://doi.org/10. $1111 /$ cdev.12036 
Newman, W. L. (1994). Social research methods: Qualitative and quantitative approaches, 2nd ed. Allyn and Bacon.

Nikčević-Milković, A., Biljan, E. i Jerković, A. (2014). Povezanost komponenti samoregulacije učenja sa školskim uspjehom i zadovoljstvom sa školom. Napredak, 155(4), 375-398.

Nikčević-Milković, A. i Perković, L. (2000). Uporaba kognitivnih strategija učenja u djece različitog školskog uzrasta. Život $i$ škola, 3, 76-93.

Oxford, R. L. (1990). Language learning strategies. U: A. Burns i J. C. Richards (Ur.), The Cambridge guide to learning English as a second language (str. 81-85). Cambridge University Press.

Pavić, J. (2015). Uloga osobina ličnosti i razredno-nastavnog ozračja u objašnjenju školskog uspjeha učenika. [Neobjavljeni diplomski rad]. Filozofski fakultet, Sveučilište u Splitu.

Pervin, L. A., Cervon, D. i John, O. P. J. (2008). Psihologija ličnosti: Teorije i istraživanja. Školska knjiga.

Pintrich, P. R. (1999). The role of motivation in promoting and sustaining self-regulated learning. International Journal of Educational Research, 31(6), 459-470. https://doi.org/10.1016/S0883-0355(99)00015-4

Poropat, A. E. (2009). A meta-analysis of the five-factor model of personality and academic performance. Psychological Bulletin, 135(2), 322-338.

Rijavec, M. i Brdar, I. (1997). Coping with school failure: Development of the school failure coping scale. European Journal of Psychology of Education, 12(1), 37-49. https://doi.org/10.1007/BF03172868

Rijavec, M., Raboteg-Šarić, Z. i Franc, R. (1999). Komponente samoreguliranog učenja i školski uspjeh. Društvena istraživanja, 8(4), 529-541.

Robbins, S. B., Lauver, K., Le, H., Davis, D., Langley, R. i Carlstrom, A. (2004). Do psychosocial and study skill factors predict college outcomes? A meta-analysis. Psychological Bulletin, 130(2), 261-288. https://doi.org/10.1037/0033-2909.130.2.261

Ryan, A. M., Shim, S., Lampkins-Thando, S. A., Kiefer, S. M. i Thompson, G. N. (2009). Gender differences in help avoidance vary by ethnicity? An examination of African American and European American students during early adolescence. Developmental Psychology, 45, 1152-1163.

Schwinger, M., Steinmayr, R. i Spinath, B. (2009). How do motivational regulation strategies affect achievement: Mediated by effort management and moderated by intelligence. Learning and Individual Differences, 19(4), 621-627. https://doi.org/10.1016/j. lindif.2009.08.006

Seiffge-Krenke, I. (1993). Coping behavior in normal and clinical samples: More similarities than differences? Journal of Adolescence, 16(3), 285-303. https://doi.org/10.1006/ jado. 1993.1026 
Senko, C., Durik, A. M. i Harackiewicz, J. M. (2008). Historical perspectives and new directions in achievement goal theory: Understanding the effects of mastery and performance-approach goals. U: J. Y Shah i W. Gardner (Ur.), Handbook of motivation science (str. 100-114). Guilford.

Sorić, I. (2014). Samoregulacija učenja. Možemo li naučiti učiti? Naklada Slap.

Steel, P. D. (2007). The nature of procrastination: A meta-analytic and theoretical review of quintessential self-regulatory failure. Psychological Bulletin, 133(1), 65-94. https://doi.org/10.1037/0033-2909.133.1.65

Šimić Šašić, S. i Sorić, I. (2011). Kvaliteta interakcije nastavnik-učenik: Povezanost s komponentama samoreguliranog učenja, ispitnom anksioznošću i školskim uspjehom. Suvremena psihologija, 14(1), 35-54.

Tatalović Vorkapić, S. (2012). The significance of preschool teacher's personality in early childhood education: Analysis of Eysenck's and Big Five Dimensions of personality. International Journal of Psychology and Behavioral Sciences, 2(2), 28-37. https://doi.org/ 10.5923/j.ijpbs.20120202.05

Tatalović Vorkapić, S. (2015). How much personality is important in educational context? U: M. Orel (Ur.), International Conference EDUvision 2015: Modern Approaches to Teaching Coming Generation (str. 75-83). EDUvision. https://eduvision.si/Content/ Docs/Zbornik\%20prispevkov\%20EDUvision\%202015.pdf

Tatalović Vorkapić, S. (2017). Personality and education: Contemporary issues in psychological science about personality in teacher education. U: C. Martin i D. Polly (Ur.), Handbook of research on teacher education and professional development professional development (str. 163-186). IGI Global. https://doi.org/10.4018/978-15225-1067-3.ch009

Thoits, P. A. (1986). Social support as coping assistance. Journal of Consulting and Clinical Psychology, 54(4), 416-426. https://doi.org/10.1037/0022-006X.54.4.416

Tomljenović, Ž. i Nikčević-Milković, A. (2005). Samopoštovanje, anksioznost u ispitnim situacijama i školski uspjeh kod djece osnovnoškolske dobi. Suvremena psihologija, $8(1), 51-62$.

Trautwein, U., Lüdtke, O., Schnyder, I. i Niggli, A. (2006). Predicting homework effort: Support for a domain-specific multilevel homework model. Journal of Educational Psychology, 98, 438-456. https://doi.org/10.1037/0022-0663.98.2.438

Vecchione, M., Alessandri, G. i Marsicano, G. (2014). Academic motivation predicts educational attainment: Does gender make a difference? Learning and Individual Differences, 32, 124-131. https://doi.org/10.1016/j.lindif.2014.01.003

Verkuyten, M. i Thijs, J. (2002). School satisfaction of elementary school children: The role of performance, peer relations, ethnicity and gender. Social-Indicators Research, 59(2), 203-228. https://doi.org/10.1023/A:1016279602893

Vermetten, Y. J., Lodewijks, H. G. i Vermunt, J. D. (2001). The role of personality traits and goal orientations in strategy use. Contemporary Educational Psychology, 26, 149-170. https://doi.org/10.1006/ceps.1999.1042 
Vizek-Vidović, V., Rijavec, M., Vlahović-Štetić, V. i Miljković, D. (2014). Psihologija obrazovanja. IEP.

Vrdoljak, G., Kristek, M., Jakopec, A. i Zarevski, P. (2014). Provjera modela predviđanja akademskog postignuća studenata: Uloga proaktivnosti i pristupa učenju. Suvremena psihologija, 17(2), 136-136.

Vrdoljak, G. i Vlahović-Štetić, V. (2018). Odnos ciljeva postignuća, strategija učenja i ocjena u srednjoškolskoj nastavi fizike. Psihologijske teme, 27(2), 141-157.

Williams, K. i McGillicuddy-De Lisi, A. (2000). Coping strategies in adolescents. Journal of Applied Developmental Psychology, 20(4), 537-549. https://doi.org/10.1016/S01933973(99)00025-8

\title{
Student's Personality Traits, Self-Regulation Strategies for Learning and Coping with School Failure, Age and Gender as Predictors of Objective and Subjective School Success
}

\begin{abstract}
Series of studies have confirmed the significant correlation between personality traits, selfregulation of learning and academic achievement, although these relations are not simple. Personality traits are important predictors of self-regulation of learning, and both are significant predictors of the explanation of objective and subjective school achievement (school satisfaction). The main objective of this research was to examine the extent to which demographic characteristics of students (age and gender), personality traits, the (meta)cognitive strategies of self-regulation of learning, the coping strategies with school failure and the strategy of seeking social support (as predictors) explain objective and subjective school achievement (as criteria). Total of 457 students from 6th and 8th grade of elementary school and 2nd grade of high school from four elementary and three secondary schools in the Republic of Croatia participated in the study. The results show that objective school achievement decreases as students' age increases. Female students have higher objective school achievement, as well as more conscientious students and those students who less rely on maladaptive strategies of surface cognitive information processing (which is also the most significant negative predictor of objective school success). The above set of predictors successfully explained $29 \%$ of objective school achievement as a criterion. Subjective school achievement also decreases with increased age. Students who are higher on the Agreableness, who less rely on maladaptive strategies of Protection of emotions by moving away when facing school failure, and use more adaptive strategies Ask for emotional and instrumental support from friends, have greater subjective school success. The above set of predictors successfully explained $18 \%$ of subjective school performance as a criterion.
\end{abstract}

Keywords: personality traits, self-regulation of learning strategies, student's age and gender, objective and subjective school achievement

Primljeno: 15. 6. 2019. 